\title{
A new breed of partnership
}

\author{
By Linda L. Phillips and Gail A. Kennedy
}

\section{The Kentucky-Tennessee \\ Information Alliance}

n November 1994, amidst fanfare in Knoxville, librarians and administrators from the universities of Kentucky (UK) and Tennessee (UTK) celebrated the signing of an Information Alliance. The relationship between the two libraries, located just three hours apart, has always been cordial. The two libraries are nearly equal in size of collections, staff, and operating budgets and share a public, land-grant university mission. In forming the partnership, library directors Paula Kaufman (UTK) and Paul Willis (UK) postulated that a deeper ailiance would have considerable benefits for creating new conceptions of information access, physical access to holdings, and potential reduction of interorganization duplication, such as original cataloging and staff development. The mission of the alliance is to enhance information access and services for users of both libraries through innovative approaches to cooperation.

During the week following the signing ceremony UK and UTK library management teams met at the Boone Tavern Hotel in Berea, Kentucky, for an all-day planning session that resulted in the identification of more than $50 \mathrm{ac}-$ tion strategies. Proposed activities ranged from the specialized ("identify complementary collecting areas in the Music Libraries for contemporary composers") to the general ("hold cliscussions in areas of mutual interest, such as personnel administration policies, reference procedures, statistics gathering, ideas for new resources and new projects"). From this session emerged a mission and vision statement for the Alliance, as well as six priority areas for action: 1) facilitate bibliographic and physical access to one another's collections; 2) build complementary collections; 3 ) share staff and professional expertise; 4) develop new library services; 5) seek funds to support cooperative programs; and 6) develop a strong organizational structure for the Alliance.

\section{Transcending individual efforts}

A key goal of the Alliance is to develop mechanisms that will transcend the efforts of the individuals who participate at any given time. Meetings of the library managers are now held every six months. At the spring 1995 meeting in Knoxville a group of 40 participants heard progress reports, including:

- catalogers brainstormed about the disposition of uncataloged Arabic materials at both institutions;

- library directors described plans to seek Council on Library Resources (CLR) funding for two Alliance training institutes, one to enhance science reference skills, the other to focus on management issues in the digital age;

- a planned UTK staff development trip to Indiana University and the University of Illinois, expanded to include UK staff;

- UTK librarians provided conspectus training for UK librarians;

- UK and UTK archivists discussed possibilities for digital preservation projects;

- the UK agriculture librarian now mentors the new UTK agriculture librarian.

At each semiannual gathering the group expects to discuss an information issue of pressing concern in both libraries. In spring 1995, Carol Tenopir from UTK's School of Information Sciences led a discussion on information technology planning in the libraries, with emphasis on electronic resources. Counterparts met to continue conversations that had been started by telephone and e-mail. 


\section{Where is the alliance headed?}

Several of the action items proposed in fall 1994 have already been completed. The 1995 joint staff development trip was deemed a rousing success by the 50 participants from the two libraries, and a 1996 trip is in the planning stages. Systems librarians established a UK-UTK listserver that is used for communicating Alliance activities. A proposal to offer two Alliance training institutes has been developed, for which CLR may assist with funding. Discussions among counterparts are ongoing - in cataloging, systems, collection development, distance education, preservation, agriculture, music, maps, etc. UTK library faculty are participating in a research project on future library roles that a UK library science professor developed and administered to UK library faculty, and the re sults will be compared. The agenda for the next managers' meeting includes progress reports, planning for 1996, and a discussion on the changing roles of academic librarians.

\section{What's in the Information Alliance for library users?}

Faculty in Arabic studies from both institutions have been working with librarians to review

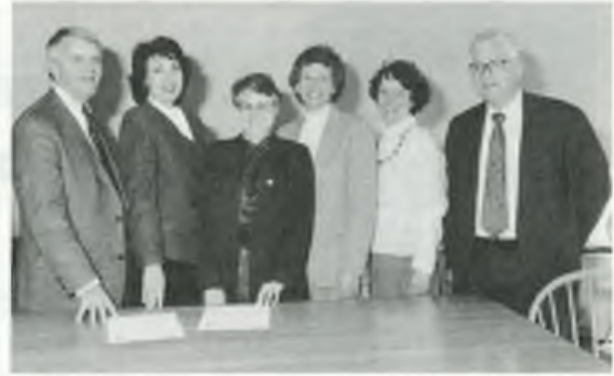

Signing the Information Alliance: Eugene Williams (UK), Gail Kennedy (UK), Paula Kaufman (UTK), Linda Phillips (UTK), Marian Moffett (UTK), and Paul Willis (UK).

the uncataloged collections, and a UK student who reads Arabic has been identified to assist catalogers with transliteration. As records are added to the local catalogs and OCLC, scholars around the world will benefit from the Alliance. The Information Alliance is creating the infrastructure for library users to receive enhanced service across a spectrum of possibilities, from expedited interlibrary loan to subject specialist availability. This partnership promises to give new depth and meaning to library cooperation.

\section{Elegant Solutions for Preservation}

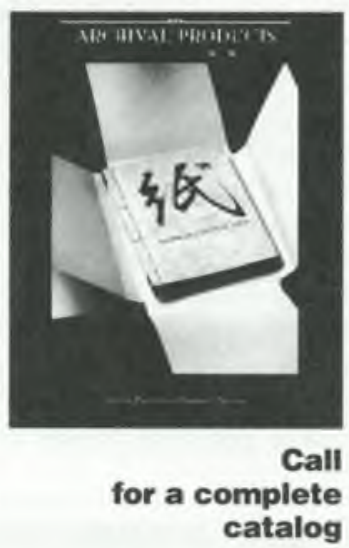

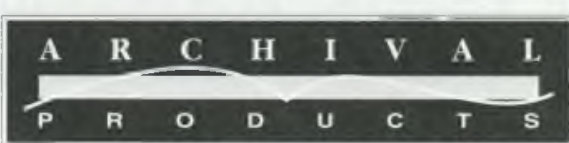

Protective Enclosures

Pamphlet Binders

Music Binders

Bound Four Flap Enclosures

Tan Archival Board

Grev/White Archival Board

Drop Spine Archival Boxes

Academy Folder

Manuscript Folder

2134 E Grand Averue

Des Moines, Iowa 50305

PH. 800.526.5640

FAX 515.262.6013

e-mail INET:70670,2635@compuserve.com 